US Army Corps of Engineers ${ }_{\circledast}$

\title{
Mississippi River and Tributaries Future Flood Conditions
}

MRG\&P Report No. 28 • September 2019

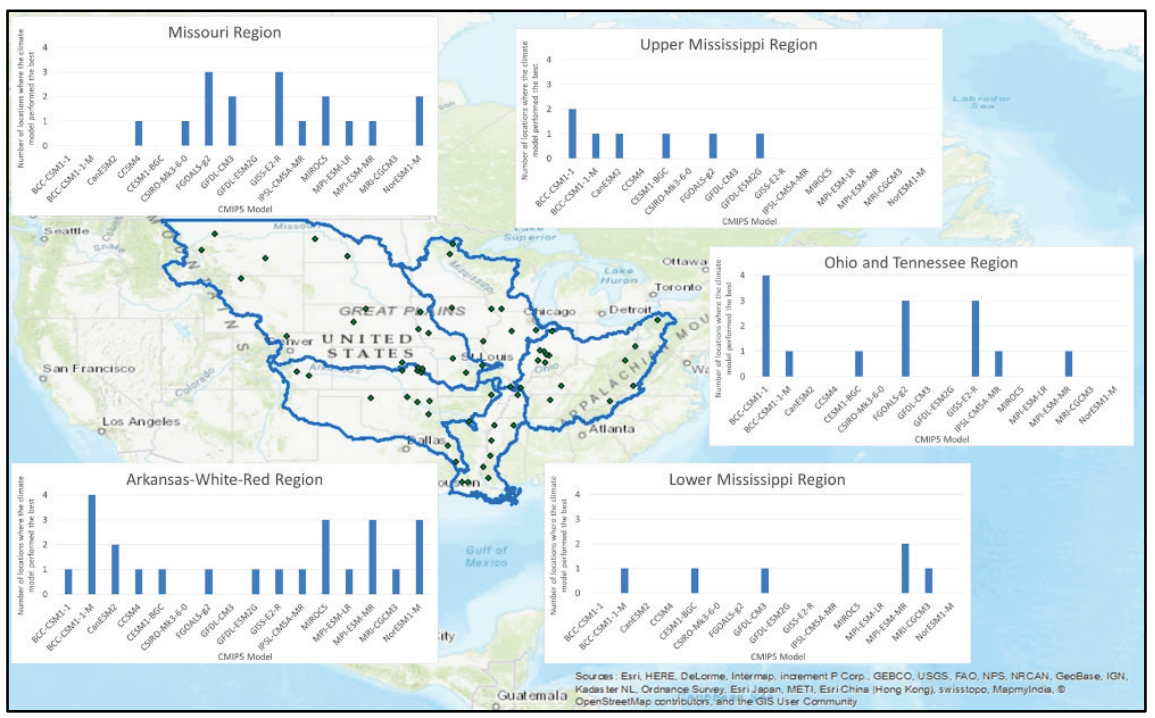

MRG\&P

Mississippi River Geomorphology \& Potamology Program 


\section{Mississippi River and Tributaries Future Flood Conditions}

James W. Lewis, Ahmad A. Tavakoly, Charles A. Martin, and Christine D. Moore

Coastal and Hydraulics Laboratory

U.S. Army Engineer Research and Development Center 3909 Halls Ferry Road

Vicksburg, MS 39180-6199

Final report

Approved for public release; distribution is unlimited.

Prepared for U.S. Army Corps of Engineers, Mississippi Valley Division, Mississippi River Geomorphology and Potamology Program 1400 Walnut Street Vicksburg, MS 39180

Under Project 470711, “Mississippi River Geomorphology and Potamology Program” 


\section{Abstract}

The Mississippi River and Tributaries Project is designed according to the Project Design Flood (PDF), or the largest storm series with a reasonable chance of occurrence over the Mississippi River Basin. This report considers a new approach to generate hypothetical extreme flow conditions for the entire Mississippi River Basin. Utilizing recent advancements in computer modeling and climate science, a vector-based continental-scale river routing model was developed for the entire Mississippi River Basin. Daily flows within all river segments were computed for 1.2 million river reaches over the time period of 1950 through 2099 and for 16 different climate scenarios. An ensemble of varying climate simulations were executed using the Routing Application for Parallel computatIon of Discharge river routing model. The 16 projections were from the Coupled Model Intercomparison Project, Phase 5, climate model projections. Daily flow results for the 65 key locations were analyzed for the historical (1950-2005) and the projected (2006-2099) time periods. Results indicate that the hydrologic conditions of the Mississippi River are not stationary and that discharges associated with the extreme events are projected to increase in the future.

DISCLAIMER: The contents of this report are not to be used for advertising, publication, or promotional purposes. Citation of trade names does not constitute an official endorsement or approval of the use of such commercial products. All product names and trademarks cited are the property of their respective owners. The findings of this report are not to be construed as an official Department of the Army position unless so designated by other authorized documents. 


\section{Contents}

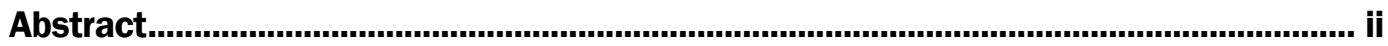

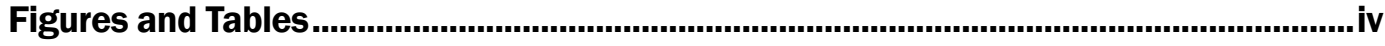

Preface

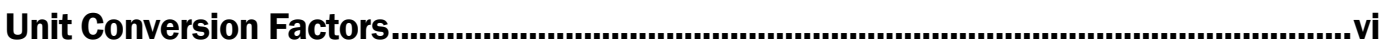

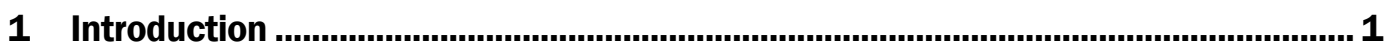

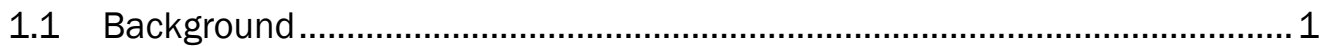

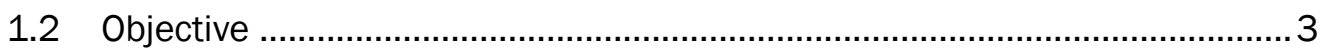

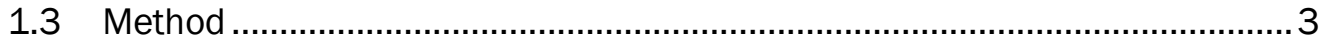

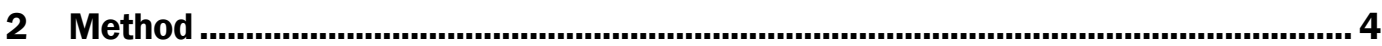

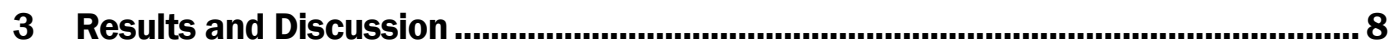

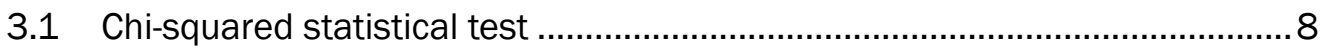

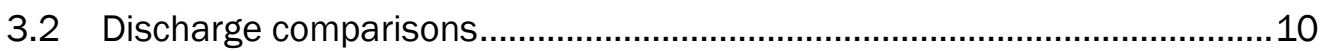

3.3 Recurrence interval analysis.................................................................

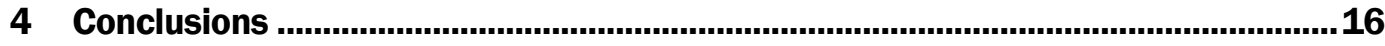

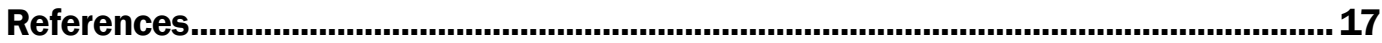

Appendix: Recurrence Interval Analysis for Additional Locations.................................20

Report Documentation Page 


\section{Figures and Tables}

\section{Figures}

Figure 1. Selected locations for the analysis of Mississippi River flows. .............................. 2

Figure 2. Map of 65 locations selected for comparison of results....................................... 4

Figure 3. Results of the chi-squared test for all gauges in the study. ................................. 9

Figure 4. Chi-squared model results by region.................................................................. 10

Figure 5. FGOALS-g2 model results for the historical time period (1950-2005) for the Ohio River at Metropolis, IL. ......................................................................... 12

Figure 6. FGOALS-g2 model annual maximum results for the entire simulation time period (1950-2099) for Metropolis, IL.

Figure 7. Recurrence interval comparisons for the 1951-2005 time period for the Ohio River at Metropolis, IL.

Figure 8. Comparison of recurrence interval changes between the historic and future time periods for the Ohio River at Metropolis, IL

Figure 9. Recurrence interval comparisons for the 1951-2005 time period for the Mississippi River at Thebes, IL.

Figure 10. Comparison of recurrence interval changes between the historic and future time periods for the Mississippi River at Thebes, IL

Figure 11. Recurrence interval comparisons for the 1951-2005 time period for the Mississippi River at Helena, AR.

Figure 12. Comparison of recurrence interval changes between the historic and future time periods for the Mississippi River at Helena, AR

Figure 13. Recurrence interval comparisons for the 1951-2005 time period for the Mississippi River at Vicksburg, MS

Figure 14. Comparison of recurrence interval changes between the historic and future time periods for the Mississippi River at Vicksburg, MS.

Figure 15. Recurrence interval comparisons for the 1951-2005 time period for the Mississippi River at Natchez, MS.

Figure 16. Comparison of recurrence interval changes between the historic and future time periods for the Mississippi River at Natchez, MS.

\section{Tables}

Table 1. List of the 16 models selected for this report. 


\section{Preface}

The research documented in this report was conducted as part of the Mississippi River Geomorphology and Potamology (MRG\&P) Program, Project 470711, "Mississippi River Geomorphology and Potamology Program.” The MRG\&P is part of the Mississippi River and Tributaries Program and is managed by the U.S. Army Corps of Engineers (USACE), Mississippi Valley Division (MVD), and districts. At the time of publication of this report, the MRG\&P Program Director was Dr. James W. Lewis. The MVD Commander was MG R. Mark Toy. The MVD Director of Programs was Mr. James A. Bodron.

Acknowledgment is presented to the World Climate Research Programmes Working Group on Coupled Modeling, which is responsible for the Coupled Model Intercomparison Project (CMIP), and gratitude is expressed to the climate modeling groups for producing and making available their model output. For CMIP, the U.S. Department of Energys Program for Climate Model Diagnosis and Intercomparison provides coordinating support and leads development of software infrastructure in partnership with the Global Organization for Earth System Science Portals.

The work was performed by the River and Estuarine Engineering Branch of the Flood and Storm Protection Division, U.S. Army Engineer Research and Development Center, Coastal and Hydraulics Laboratory (ERDC-CHL). At the time of publication of this report, Mr. Keith Flowers was Chief of the River and Estuarine Engineering Branch; Dr. Cary Talbot was Chief of the Flood and Storm Protection Division. The Deputy Director of ERDC-CHL was Mr. Jeffrey R. Eckstein, and the Director was Dr. Ty V. Wamsley.

The Commander of ERDC was COL Teresa A. Schlosser, and the Director was Dr. David W. Pittman.

The work here represents a research and development effort and is not intended for use in USACE planning or design. 


\section{Unit Conversion Factors}

\begin{tabular}{|l|c|l|}
\hline Multiply & By & To Obtain \\
\hline acres & $4,046.873$ & square meters \\
\hline acre-feet & $1,233.5$ & cubic meters \\
\hline cubic feet & 0.02831685 & cubic meters \\
\hline cubic inches & $1.6387064 \mathrm{E}-05$ & cubic meters \\
\hline cubic yards & 0.7645549 & cubic meters \\
\hline degrees Fahrenheit & $(\mathrm{F}-32) / 1.8$ & degrees Celsius \\
\hline feet & 0.3048 & meters \\
\hline gallons (U.S. liquid) & $3.785412 \mathrm{E}-03$ & cubic meters \\
\hline hectares & $1.0 \mathrm{E}+04$ & square meters \\
\hline inches & 0.0254 & meters \\
\hline miles (U.S. statute) & $1,609.347$ & meters \\
\hline square feet & 0.09290304 & square meters \\
\hline square miles & $2.589998 \mathrm{E}+06$ & square meters \\
\hline
\end{tabular}




\section{Introduction}

\subsection{Background}

The magnitude of future floods is of critical importance to the Mississippi River and Tributaries (MR\&T) system's design capacity for flood protection and functionality as an efficient and reliable waterway. In 2011, the MR\&T protection system performed as designed and handled one of the largest flood events in recorded history. The U.S. Army Corps of Engineers (USACE) conducted an evaluation of the MR\&T flood risk management system, published in the MR\&T 2011 Post Flood Report (DeHaan et al. 2012). The MR\&T Meteorology Review of 2012 (Gaines et al. 2018, Appendix H) concluded that the combinations of historic and hypothetical storms developed in 1955 (MRC 1955) are still valid and adequate for creation of the PDF for the MR\&T system. The PDF is defined as the largest storm series considered to have a reasonable chance of occurrence in the season when floods are likely to occur over the Mississippi River Basin (MRB). The MR\&T Flowline Assessment (Gaines et al. 2018) used the meteorology events developed in 1955 with current National Weather Service hydrologic models. However, a large body of scientific research has demonstrated a changing climate and nonstationary conditions. According to the best of the authors' knowledge, there has not been an effort to evaluate the MR\&T system by incorporating climate change projections from the entire basin in terms of the combined flow in the mainstem of the river.

This report considers an entirely different approach for studying the potential range of extreme events that could occur within the MRB. During 2012-2013, the World Climate Research Programme released global climate projections from the Coupled Model Intercomparison Project, Phase 5 (CMIP5) multi-model ensemble, which built upon the previous CMIP, Phase 3 . CMIP 5 features climate projections using a new generation of global climate models representing recent advancements in climate science and an updated set of global greenhouse gas emissions scenarios (Flato et al. 2013; Taylor et al. 2012). The CMIP5 projections were downscaled using a Bias-Correction Spatial Disaggregation (BCSD) technique over the contiguous United States. The Variable Infiltration Capacity (VIC) hydrology model, version 4.1.2

(http://www.hydro.washington.edu/Lettenmaier/Models/VIC) was used to generate daily 
total runoff from 1950 through 2099 for a subset of 97 climate projections, representing 31 different climate models and 4 different greenhouse gas emissions scenarios. The VIC model output is available in netCDF file format at a grid size of $1 / 8$ degree by $1 / 8$ degree, or approximately a 12-kilometer $(\mathrm{km})$ resolution (Brekke et al. 2014). This report documents how a vector-based, continental-scale river routing model uses the VIC model output to generate daily flows within all the river segments of the entire MRB leading to projections of future flood conditions within the basin.

To assess climate change on the mainstem of the Mississippi River, five key locations were chosen, as shown in Figure 1; each of these has a longterm historical gage record. Two of the locations show the contributions of the Ohio River and Mississippi River just upstream of their confluence. The Metropolis, IL, station is located near the downstream end of the Ohio River, and the Thebes, IL, station is located within the Mississippi River just upstream of the confluence. The other three gages are along the mainstem of the Lower Mississippi River at Helena, AR; Vicksburg, MS; and Natchez, MS.

Figure 1. Selected locations for the analysis of Mississippi River flows.

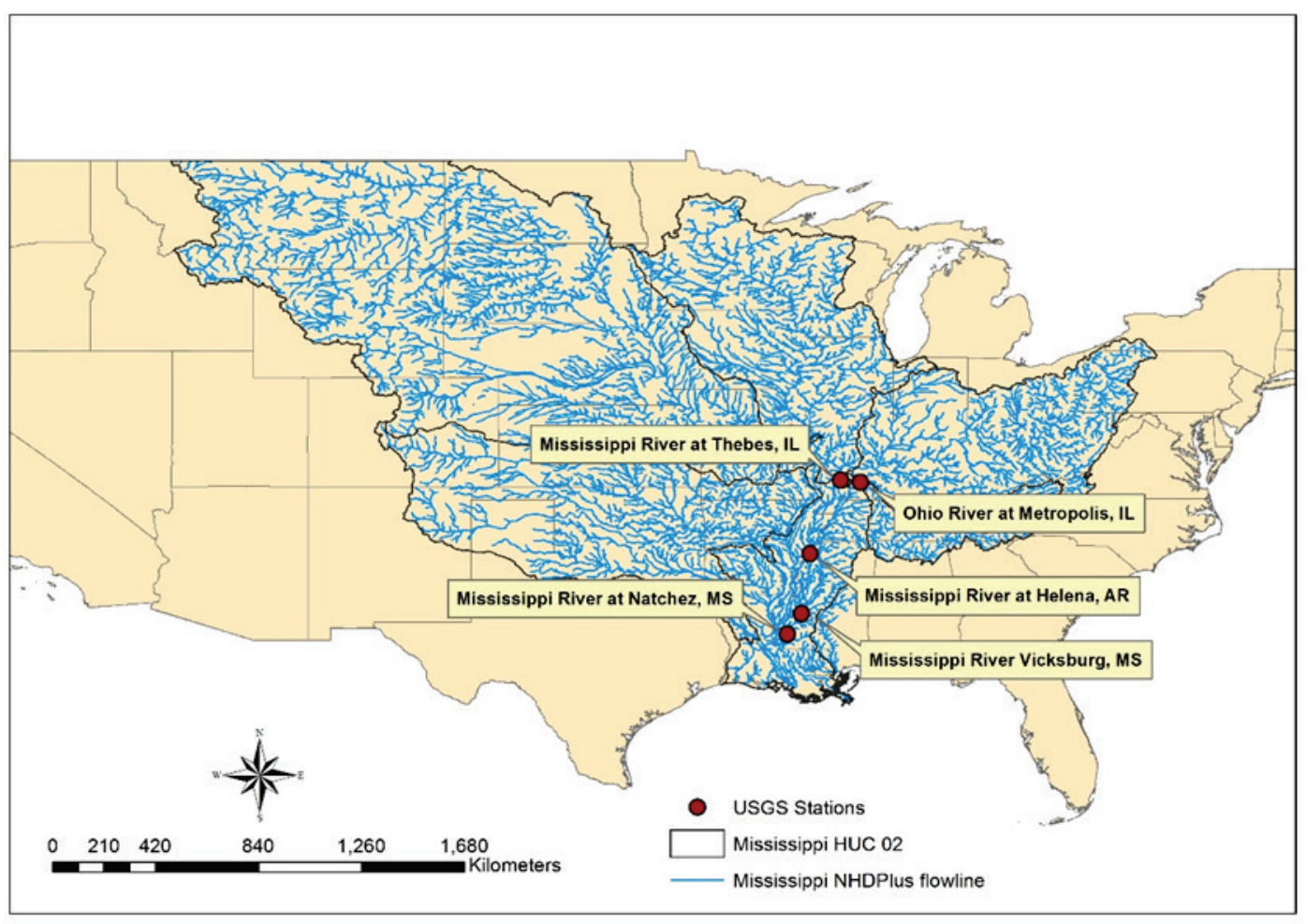




\subsection{Objective}

The objective of this report is to assess a range of potential future high flow conditions throughout the Mississippi River Basin (MRB).

\subsection{Method}

The method is presented in Chapter 2. 


\section{Method}

The NHDPlus V2 dataset is a vector-based dataset that describes river segments as blue lines with polygon shapefiles of catchments surrounding them for the entire contiguous United States (NHDPlus; Horizon Systems Corporation [2007]). This dataset contains approximately 2.7 million river reaches for the contiguous United States of which 1.2 million are within the MRB. This dataset assigns a unique identity for each river segment in addition to other attributes that can be used to determine connections between river reaches and therefore create the river network. Based on the Hydrologic Unit Codes (HUC), the United States is divided into 18 regions, 6 of which represent the entire MRB, including HUC 05, 06, 07, 08, 10 (10U upper and 10L lower regions), and 11. Using the ArcGIS (ESRI 2011) "Merge" tool, the river network and catchment shapefiles of individual HUC datasets were merged to create a geographic information system (GIS) river network and catchments for the entire MRB (Figure 1). The attribute table of the NHDPlus dataset shows that the MRB has a total of $1,240,697$ river reaches with an average length and catchment area of 1.93 $\mathrm{km}$ and $2.7 \mathrm{~km}^{2}$, respectively. Moreover, the location of U.S. Geological Survey (USGS) gauges is included in the NHDPlus dataset as a shapefile. In addition to the 5 key locations shown in Figure 1, 60 other locations were selected for comparison where large amounts of historical discharge data were available. A total of 65 selected locations are spread across the MRB as shown in Figure 2. In this figure, the blue lines represent the extent of the MRB as divided by the two-digit HUC drainage regions.

Figure 2. Map of 65 locations selected for comparison of results.

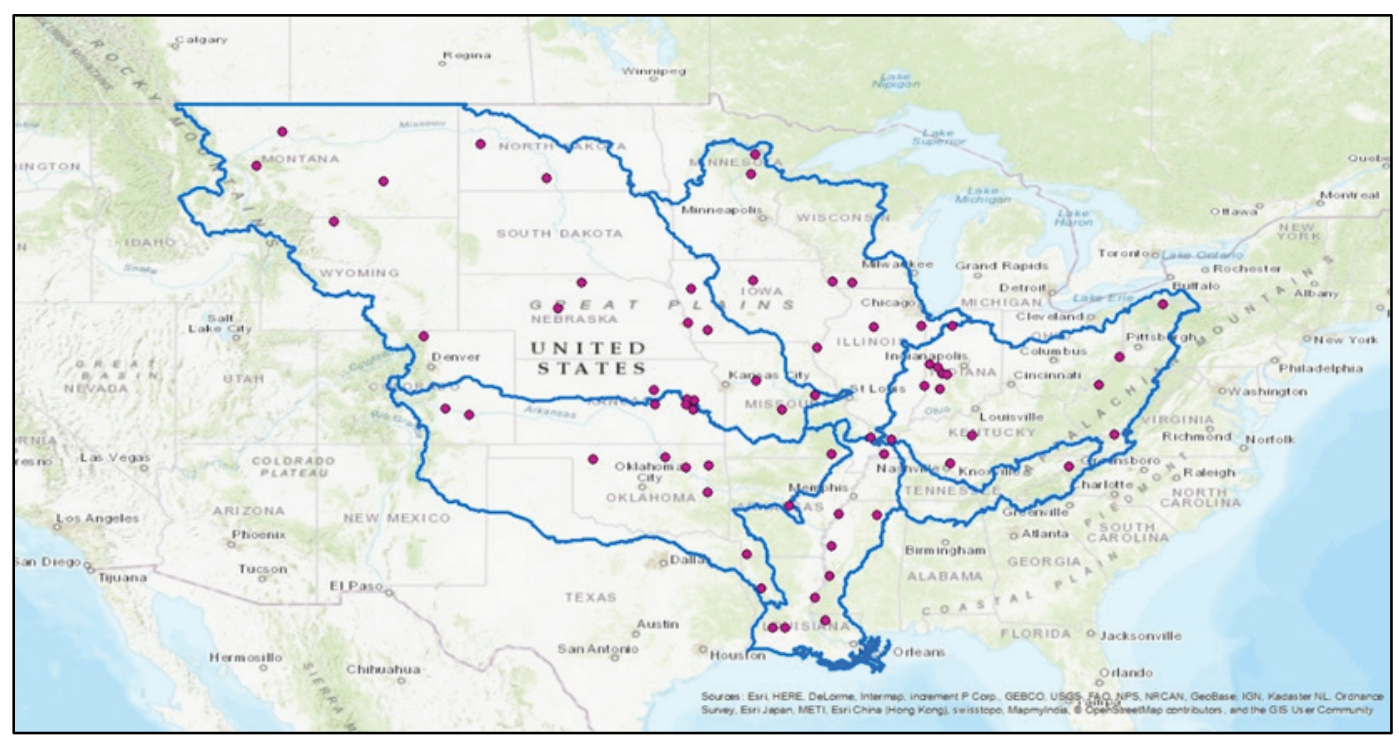


The Routing Application for Parallel computatIon of Discharge (RAPID) is an open-source river routing model that computes river discharge and can be implemented over very large river networks due to an efficient parallelization method (David et al. 2015). This model can be run on different types of river networks including traditional grid-based river networks (David et al. 2011a; Tavakoly 2019) and vector-based (mapped blue lines) river networks (David et al. 2011b, 2013; Tavakoly et al. 2016, 2017). The RAPID model takes runoff generated by land surface models and uses a matrix-based Muskingum method to calculate streamflow for each river reach in the study domain. With more than a decade of development, the RAPID model has been applied in different fields and domains including river-aquifer interactions in France (Saleh et al. 2011; Flipo et al. 2012; Thierion et al. 2012; Tavakoly et al. 2019), continentalscale flow modeling of the MRB (Tavakoly et al. 2017), reservoir storage simulations (Lin et al. 2015), high-resolution flood inundation mapping (Follum et al. 2017), total nitrogen transport modeling in Texas (Tavakoly et al. 2016), and a national hydrologic forecast system (Snow et al. 2016). The RAPID model simulations in this investigation do not include any reservoir regulation effects. However, this is acceptable since the focus of this investigation is to compare changes in discharges between the historical and future time periods.

$\mathrm{CMIP}_{5}$ climate projection data were obtained from the downscaled $\mathrm{CMIP}_{3}$ and $\mathrm{CMIP}_{5}$ Climate and Hydrology Projections archive at http://gdodcp.ucllnl.org/downscaled_cmip_projections. This effort analyzed 16 of the 31 available climate models for one greenhouse gas emissions scenario. The greenhouse gas emissions scenario used in this analysis is referred to as the representative concentration pathway 4.5 ( $\mathrm{RCP} 4.5)$, and it is in between the high (RCP 8.5) and low (RCP 2.6) greenhouse gas emissions scenarios of CMIP 5 . RCP 8.5 is a scenario where emissions continue to rise throughout the twenty-first century whereas RCP 2.6 is a scenario where emissions peak between 2010 and 2020 and then substantially decline. $\mathrm{RCP} 4.5$ is a scenario where emissions increase through the 2040 s and then decline within $\mathrm{CMIP}_{5}$. There was also a fourth emissions scenario considered within $\mathrm{CMIP}_{5}$ known as RCP 6.0, but hydrology projections for RCP 6.0 were only available from half of the 31 total climate models.

The selection of the 16 CMIP 5 climate models used in this analysis was based on accuracy rankings available within the literature for either precipitation or runoff. Törnqvist et al. (2014) assessed 22 CMIP 5 models for the Lake Baikal 
basin, providing performance rankings based on monthly precipitation, temperature, evapotranspiration, and runoff. Ahmadalipour et al. (2015) analyzed the performance of 20 models for the Columbia River Basin in terms of both precipitation and temperature at the daily and monthly time scales. Table 1 lists the 16 models that were chosen to be used for this analysis and the associated climate modeling group.

Table 1. List of the 16 models selected for this report.

\begin{tabular}{|c|c|}
\hline CMIP5 Climate Model ID & CMIP5 Climate Modeling Group* \\
\hline BCC-CSM1-1 & \multirow{2}{*}{ Beijing Climate Center, China Meteorological Administration } \\
\hline BCC-CSM1-1-M & \\
\hline CanESM2 & Canadian Centre for Climate Modelling and Analysis \\
\hline CCSM4 & National Center for Atmospheric Research \\
\hline CESM1-BGC & Community Earth System Model Contributors \\
\hline CSIRO-Mk3-6-0 & $\begin{array}{l}\text { Commonwealth Scientific and Industrial Research Organization, } \\
\text { Queensland Climate Change Centre of Excellence }\end{array}$ \\
\hline FGOALS-g2 & $\begin{array}{l}\text { Laboratory of Numerical Modeling for Atmospheric Sciences and } \\
\text { Geophysical Fluid Dynamics, Institute of Atmospheric Physics, } \\
\text { Chinese Academy of Sciences, and Center for Earth System Science, } \\
\text { Tsinghua University }\end{array}$ \\
\hline GFDL-CM3 & \multirow{2}{*}{ NOAA Geophysical Fluid Dynamics Laboratory } \\
\hline GFDL-ESM2G & \\
\hline GISS-E2-R & NASA Goddard Institute for Space Studies \\
\hline IPSL-CM5A-MR & Institut Pierre-Simon Laplace \\
\hline MIROC5 & $\begin{array}{l}\text { Atmosphere and Ocean Research Institute (The University of Tokyo), } \\
\text { National Institute for Environmental Studies, and Japan Agency for } \\
\text { Marine-Earth Science and Technology }\end{array}$ \\
\hline MPI-ESM-LR & \multirow{2}{*}{$\begin{array}{l}\text { Max-Planck-Institut für Meteorologie (Max Planck Institute for } \\
\text { Meteorology) }\end{array}$} \\
\hline MPI-ESM-MR & \\
\hline MRI-CGCM3 & Meteorological Research Institute \\
\hline NorESM1-M & Norwegian Climate Centre \\
\hline
\end{tabular}

*Note: http://cmip-pcmdi.IInl.gov/cmip5/docs/CMIP5_modeling_groups.pdf

The VIC products selected for this study use a specific statistical downscaling approach (BCSD) to downscale (and bias-correct) raw $\mathrm{CMIP}_{5}$ precipitation and temperature outputs. After BCSD, the downscaled precipitation and temperature values have the same monthly distribution compared to the chosen gridded observation (Maurer et al. 2002); this effort was primarily led by the Bureau of Reclamation. (More details can 
be found in the Reclamation technical report [Brekke et al. 2014].) The downscaled precipitation and temperature values are then used to drive the $12 \mathrm{~km}$ VIC model used by the National Center for Atmospheric Research. The CMIP5-BCSD-VIC was not further bias-corrected.

To route the streamflow through the MRB, the RAPIDpy python preprocess tool (https://github.com/erdc/RAPIDpy or http://rapidpy.readthedocs.io/en/stable/) was developed to create RAPID runoff files based on the 1/8 degree CMIP 5 dataset, therefore generating a weight table and runoff file for each catchment in the MRB. Daily data for each year are available in one netCDF file. Hence, there are 150 netCDF files containing data from 1950 through 2099 for each GCM ensemble member. These netCDF files of hydrologic (VIC model) output were utilized to obtain daily total runoff. The RAPID runoff input files were then created in the netCDF format for the 16 selected models for this study and 150 years of simulation time period. The Muskingum parameters " $K$ " and " $\mathrm{x}$ " relied on previous work to be defined in the RAPID model. Tavakoly et al. (2017) calibrated the RAPID model using VIC runoff dataset for the MRB and explained the calibration process in detail. They showed that channel geometries including river length and slope are the key factors in the RAPID calibration. To be consistent for CMIP5 model comparisons, the same set of " $K$ " and " $\mathrm{x}$ " parameters calibrated by Tavakoly et al. (2017) were used in this study. Furthermore, both studies use the same river network and land surface model (VIC). The preprocessing steps were performed using a Linux Ubuntu desktop computer, but the main simulations were performed using the U.S. Army Engineer Research and Development Center, Topaz high-performance computer (SGI ICE X, https://www.erdc.hpc.mil/about/index.html). To optimize the simulations on Topaz, runs were split apart into approximately 8-year time intervals, primarily based on memory utilization, queue time, and run-time. Initial flows were set to zero for each run, and it took approximately 25 days of spinup time for the flows in the model to become independent of the initial flows. For this reason, an overlapping year was used for each run to cover the warm-up time.

Historical daily flow records were obtained for the Vicksburg, MS, and Natchez, MS, locations from the USACE Vicksburg District office. The historical daily flow records for Helena, AR, were obtained from the USACE Memphis District Office. Historical daily flow records for Metropolis, IL; Thebes, IL; and the 60 other selected locations were obtained from the USGS National Water Information System (site numbers 07022000 for Thebes and 03611500 for Metropolis). 


\section{Results and Discussion}

\subsection{Chi-squared statistical test}

The goal of the $\mathrm{CMIP}_{5}$ climate models is to reasonably simulate the overall trend and distribution of climatological and hydrological patterns, not the year-to-year inter-annual variability. The climate model simulations cannot reproduce the year-to-year inter-annual variability, even for the historical time period, though overall they may capture the range of variability and trend. Hence, time-series types of comparisons of simulated river discharges with observed discharges (e.g., root-meansquare error, correlation, Nash-Sutcliffe efficiency, Kling-Gupta efficiency) are not useful. In evaluating the historical time period, what really matters is how well the shape of the observed discharge distribution matches the shape of the simulated discharge distribution. For this purpose, chisquared statistical tests were performed.

The chi-squared test, originally developed by Pearson (2009), is a way to test the similarities between the distributions of two data sets. Sometimes it is used to test whether two samples come from the same population. It is also often used to measure the goodness-of-fit between a model and observations, as is done in this project. The chi-squared tests were performed for each of the models using any available discharge data from 1951 to 2005 for each of the gage locations. Simulation data from 1950 were not included because it was considered a warm-up year for the routing model. The analysis was implemented using the statistical software package R (R Core Team, https://www.R-project.org). The key result of the chi-squared test is a parameter called the $\mathrm{p}$-value, which represents the significance of how well the two data sets compare. The lower the p-value, the more similar the two samples are to one another.

To compare performance across the $16 \mathrm{CMIP}_{5}$ models, the best performing model for each gage location was identified (i.e., the model with the lowest p-value). Figure 3 shows the number of locations where each model performed the best. The FGOALS-g2 model had the best result at 12 of the gage locations, indicating that it is one of the better performing models in matching the distribution of discharge with the observations. The BCC-CSM1-1 model was next highest, having the lowest chi-squared p-value at eight locations. Other noteworthy models include GISS-E2-R and MPI-ESM-MR, which each had the lowest p-value at six locations, and 
BCC-CSM1-1-M and NorESM1-M each had the lowest p-value at five locations. The CSIRO-MK3-6-o model performed the worst in this test because it did not have the lowest chi-squared p-value at any location.

Figure 3. Results of the chi-squared test for all gauges in the study.

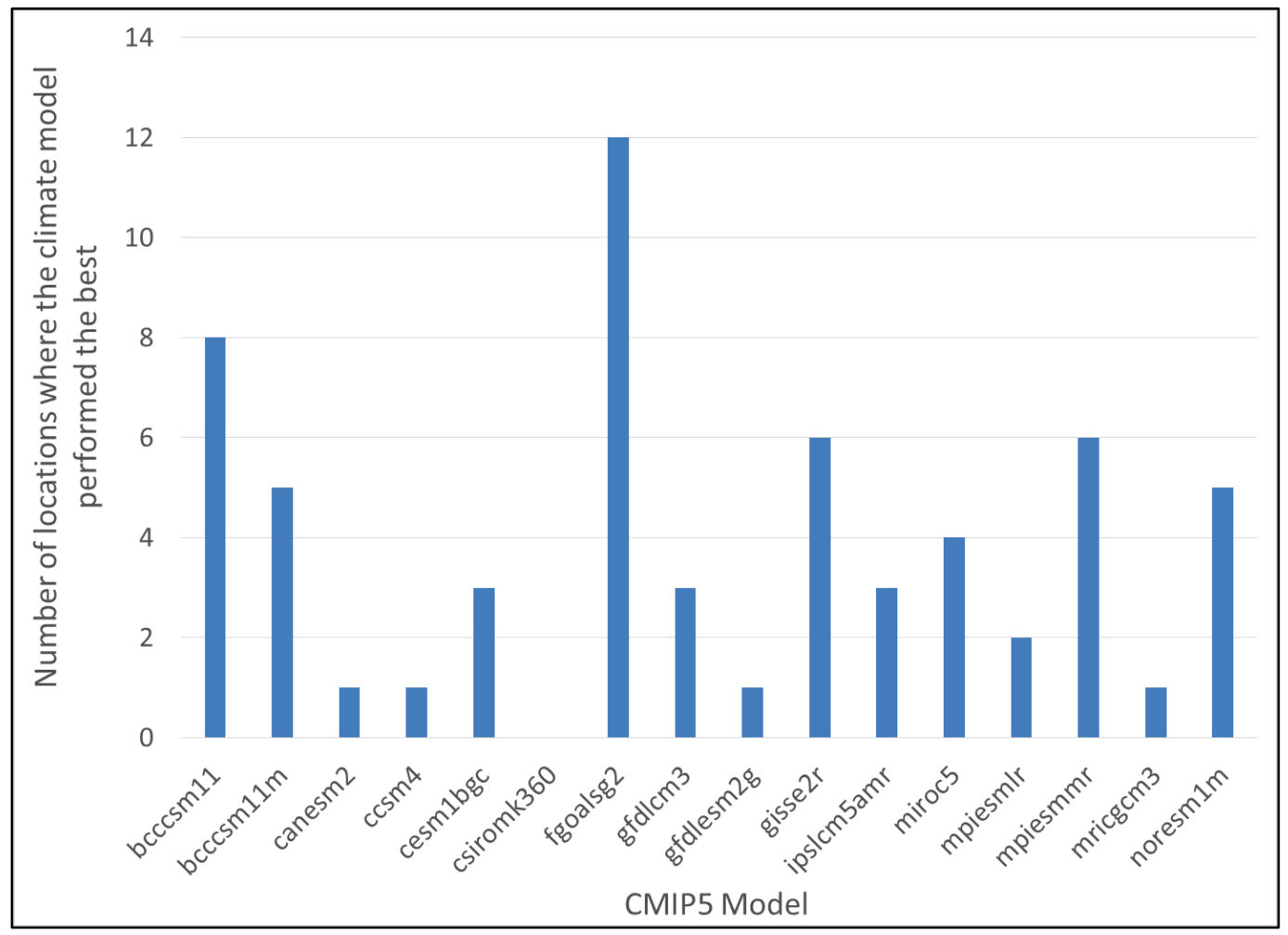

Figure 4 shows the chi-squared results of the models by region and examines whether models perform better or worse in certain parts of the basin. In the Missouri Region, FGOALS-g2 and GISS-E2-R each had three locations where they performed the best, followed by GFDL-CM3, MIROC5, and NorESM1-M each having two locations where they performed the best. BCC-CSM1-1 performed the best in both the Upper Mississippi Region and the Ohio and Tennessee Region. FGOALS-g2 and GISS-E2-R also performed relatively well in the Ohio and Tennessee Region. MPI-ESM-MR performed the best in the Lower Mississippi Region. In the Arkansas-White-Red Region, the BCC-CSM1-1-M model had four locations where it performed the best, followed by MIROC5, MPIESM-MR, and NorESM1-M, each having three locations. Another interesting result from Figure 4 is that MIROC5 and NorESM1-M seem to perform well in the western parts of the basin and not as well in the eastern parts of the basin. 
Figure 4. Chi-squared model results by region.

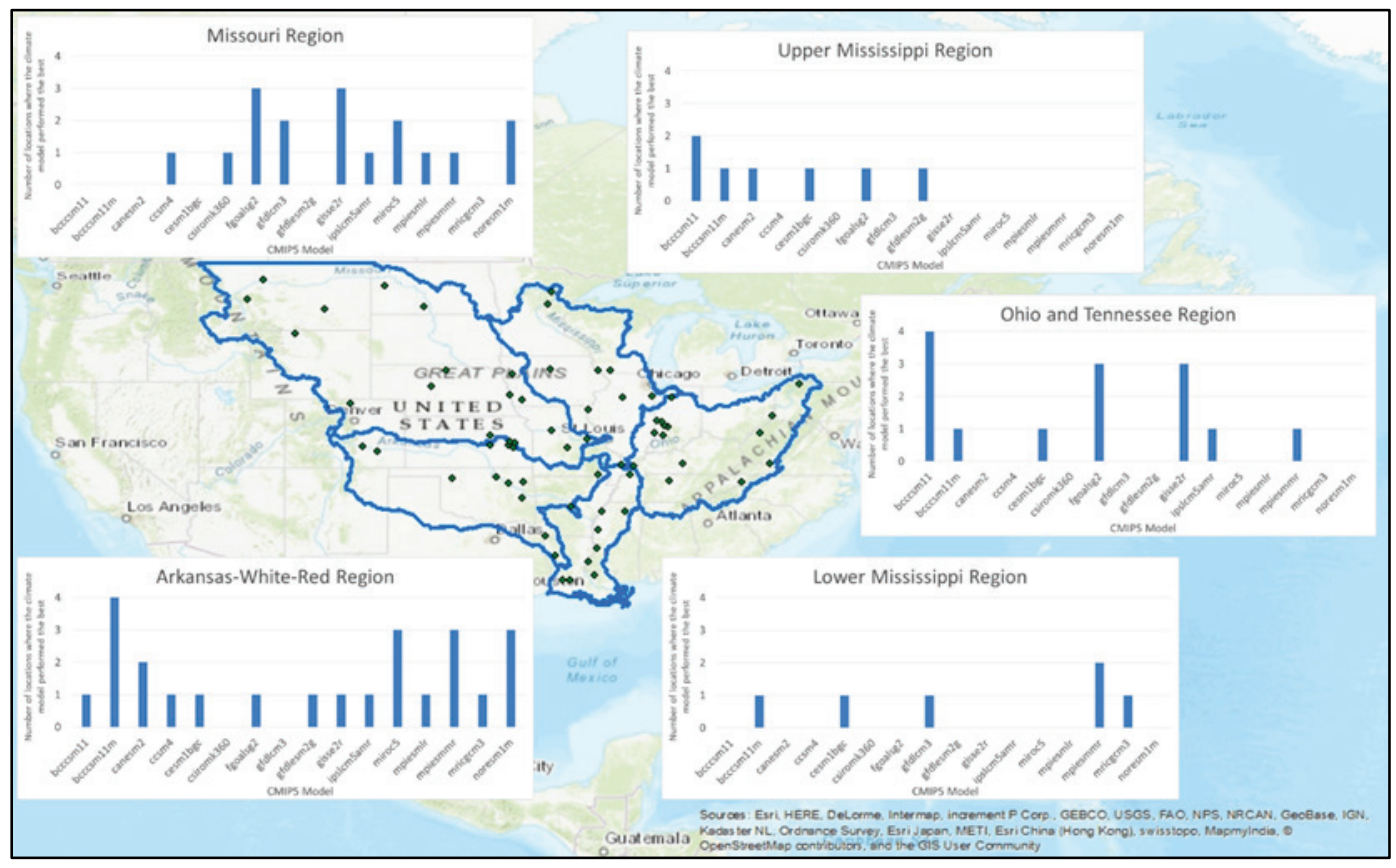

\subsection{Discharge comparisons}

Modeling results were compared with recorded data for the historical time period, from 1950 to 2005 , for the five key locations. The period of $1950-$ 2005, here referred to as the historical time period, was chosen to compare with observations since the GCMs used common emission forcing data for simulating this time period. Figure 5 shows an example of the daily results available from one of the modeling simulations, FGOALSg2, in comparison to the historical observed data at the Ohio River at Metropolis, IL. According to the USGS website (site \#03611500, https://nwis.waterdata.usgs.gov), the maximum recorded flow at this gage occurred on 1 February 1937 with a value of $1,850,000 \mathrm{cfs}$. The FGOALS-g2 results are reasonable when visually inspecting the magnitudes of peak events throughout the time period. However, an overestimation of the FGOALSg2 peak results, compared with observations for 1950-2005, is noticeable within the figure. Figure 6 shows the annual maximum FGOALS-g2 model results for the entire simulation time period (1950-2099) at Metropolis, $\mathrm{OH}$, along with observed annual maximums since 1950.

The largest source of error within the modeled flows is due to the input data for the RAPID model. This is demonstrated by the wide differences in how the climate models behave relative to one another. This significant error is caused by the separation between the climate model forcings (solar 
radiation, greenhouse gas emissions, etc.) and important variables that are generated by the climate models, such as precipitation, relative humidity, temperature, etc. In other words, even if all of the climate models perfectly match the observed forcings for the historical time period, simulated conditions such as precipitation can be significantly different from observations at any particular time. This is the most significant source of discrepancy between the modeled discharges and observed discharges for the historical time period. Other sources of error, such as the reservoir regulation effects and the routing inaccuracies, are acknowledged by the authors, but these errors are not expected to be as significant as the differences in the input data.

Note that the primary purpose of the $\mathrm{CMIP}_{5}-\mathrm{BCSD}$ runoff dataset is to provide a large ensemble of projected runoff scenarios to support the quantification of possible trends and uncertainties for future water management decisions. Although both precipitation and temperature were bias-corrected (through the BCSD approach), the macroscale hydrologic model that was used to simulate runoff was not extensively calibrated. For these reasons, some inconsistencies are shown between daily streamflow comparison and annual maximum discharges over the time period of simulations. Therefore, an appropriate evaluation should be to judge the level of relative change from baseline to future periods, not the exact prediction of peak streamflow magnitude in the future period. 
Figure 5. FGOALS-g2 model results for the historical time period (1950-2005) for the Ohio River at Metropolis, IL.

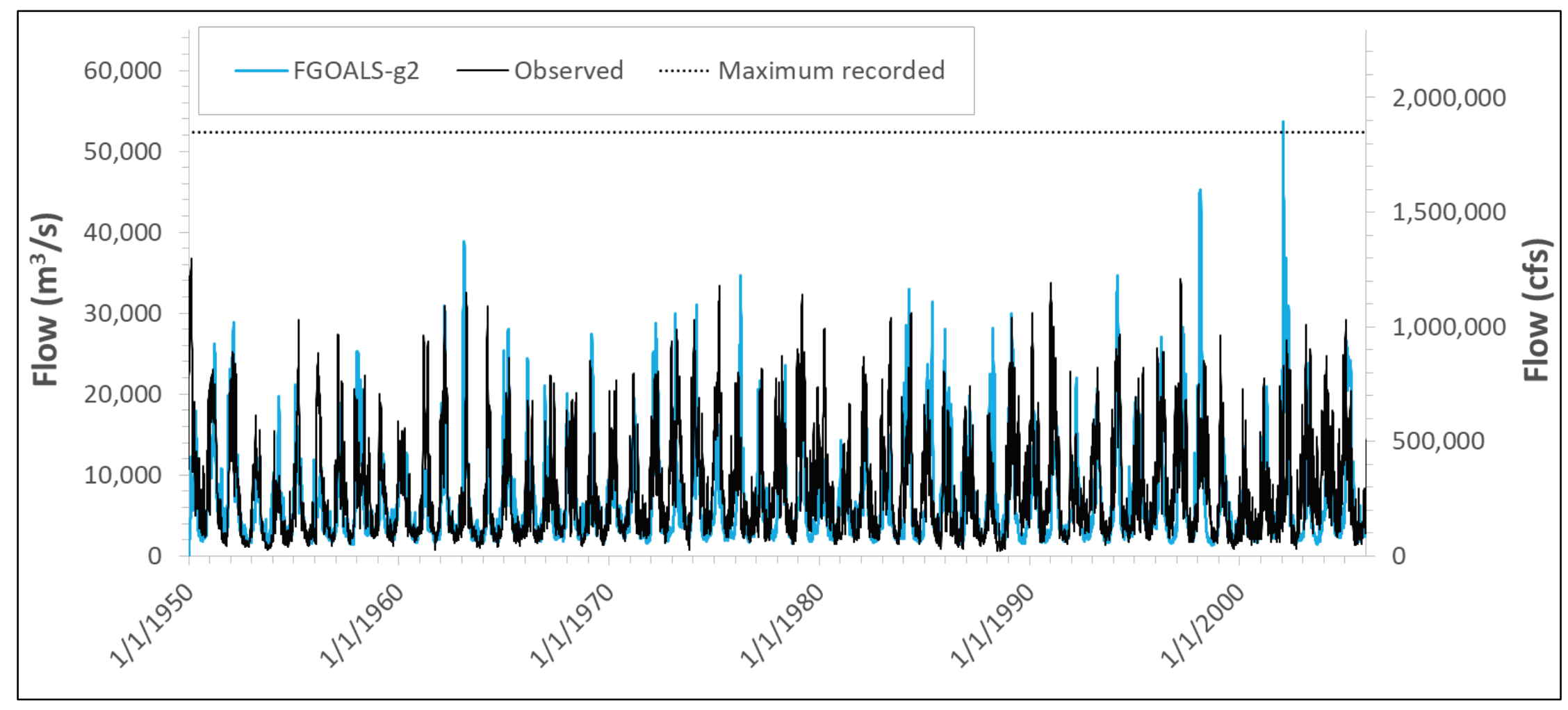


Figure 6. FGOALS-g2 model annual maximum results for the entire simulation time period (1950-2099) for Metropolis, IL.

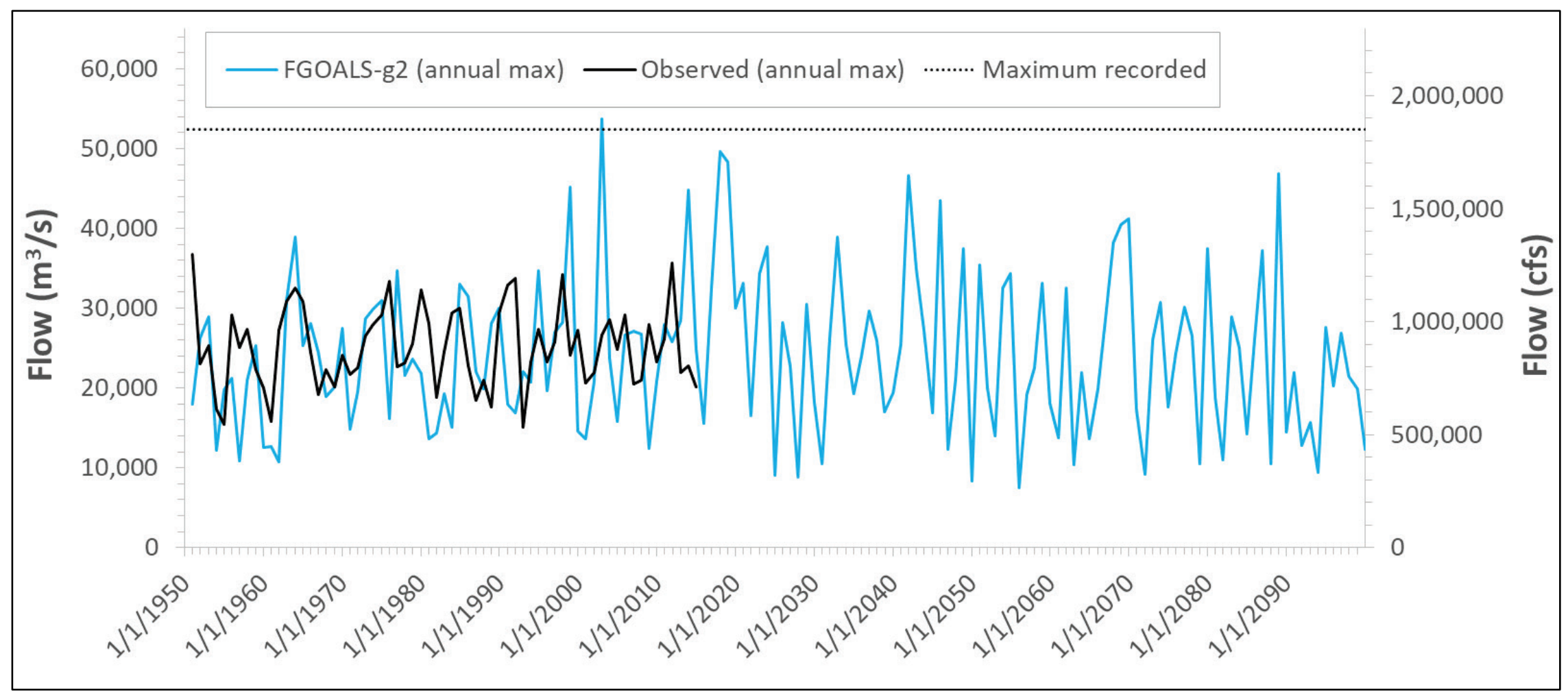




\subsection{Recurrence interval analysis}

A recurrence interval analysis is useful for the extremely high flow events. The R statistical software was used to calculate return interval values using maximum annual values and a generalized extreme value distribution for the $2,5,10,50,100,500$, and 1000-year events. Figure 7 shows the recurrence interval results for the time period 1951-2005 for the Ohio River at Metropolis, IL. The gray lines in Figure 7 show the 16 recurrence interval relationships for each of the selected CMIP5 models. The median discharge value from the 16 models at each return interval is shown in Figure 7 as the black line. The recurrence interval relationship for the historical data is shown as the black dashed line. The results show that the observed data recurrence interval values are nearly always below the CMIP5 model projections, suggesting that the $\mathrm{CMIP}_{5}$ simulations appear to be overestimating the occurrence of peak discharges during the historical time period. Recurrence interval results for other key locations of the Mississippi River (Thebes, IL; Helena, AR; Vicksburg, MS; and Natchez, MS) are available in the Appendix.

As shown in Figure 7, all of the CMIP5 models indicate higher discharges for the extreme events than the historical data. Since this 55-year time period is being used for the estimation of rare events, it takes only one or two higher flows in the $\mathrm{CMIP}_{5}$ simulation to significantly move the recurrence interval values of the extreme events.

Figure 7. Recurrence interval comparisons for the 1951-2005 time period for the Ohio River at Metropolis, IL.

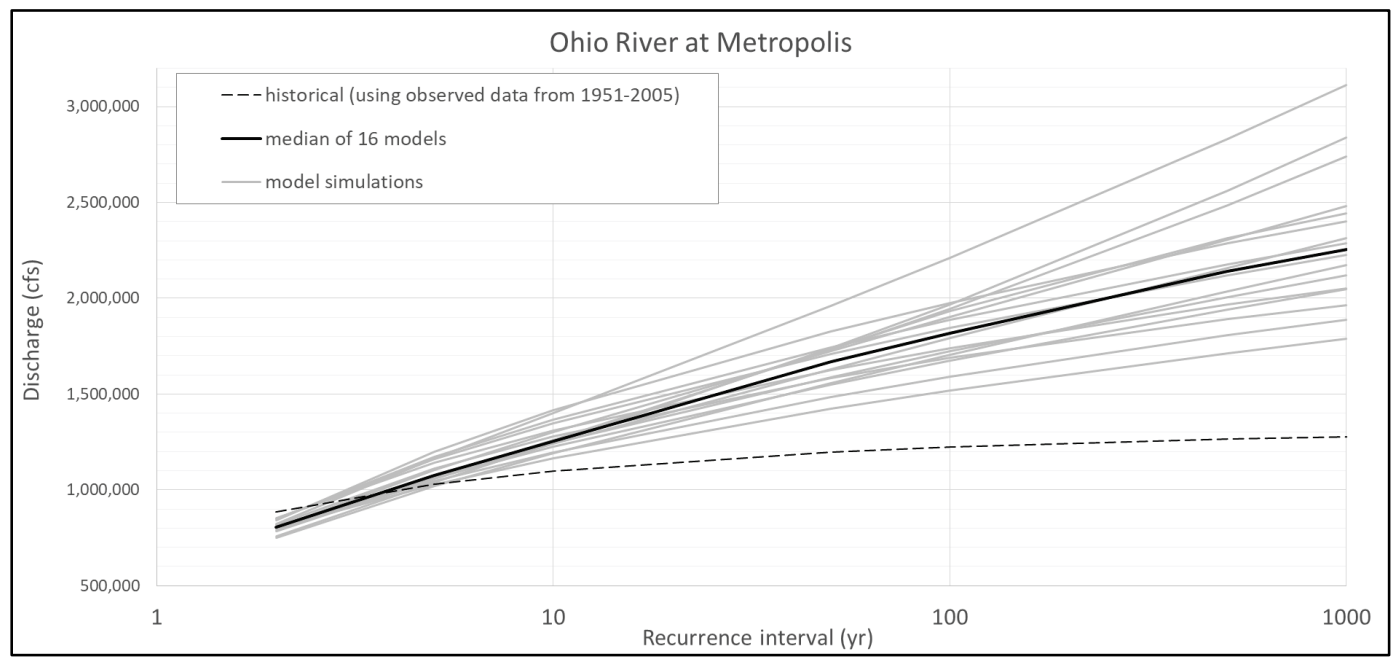


The change in recurrence interval discharge was evaluated by comparing the relationships for the 1951-2005 time period with the 2006-2099 time period, as shown in Figure 8. The solid blue line represents the median of the 16 models for the historical time period, and the solid red line is the median of the models for the future time period. The difference between the blue and red lines indicates the recurrence interval discharges are projected to increase in the future. The black dashed line represents the historical recurrence interval relationship. The projected conditions for the 2006-2099 time period are estimated by applying the change shown between the red and blue lines to the historical line. This projection is shown by the solid black line. The figure also indicates the full range of the 16 models for each of the two time periods, shown by the dashed blue and dashed red lines. The upper range of the models is much higher in the future time period, indicating that some of the climate models are projecting very large increases in the extreme events. The same type of figure is included in the Appendix for the other key locations of Thebes, IL; Helena, AR; Vicksburg, MS; and Natchez, MS.

Figure 8. Comparison of recurrence interval changes between the historic and future time periods for the Ohio River at Metropolis, IL.

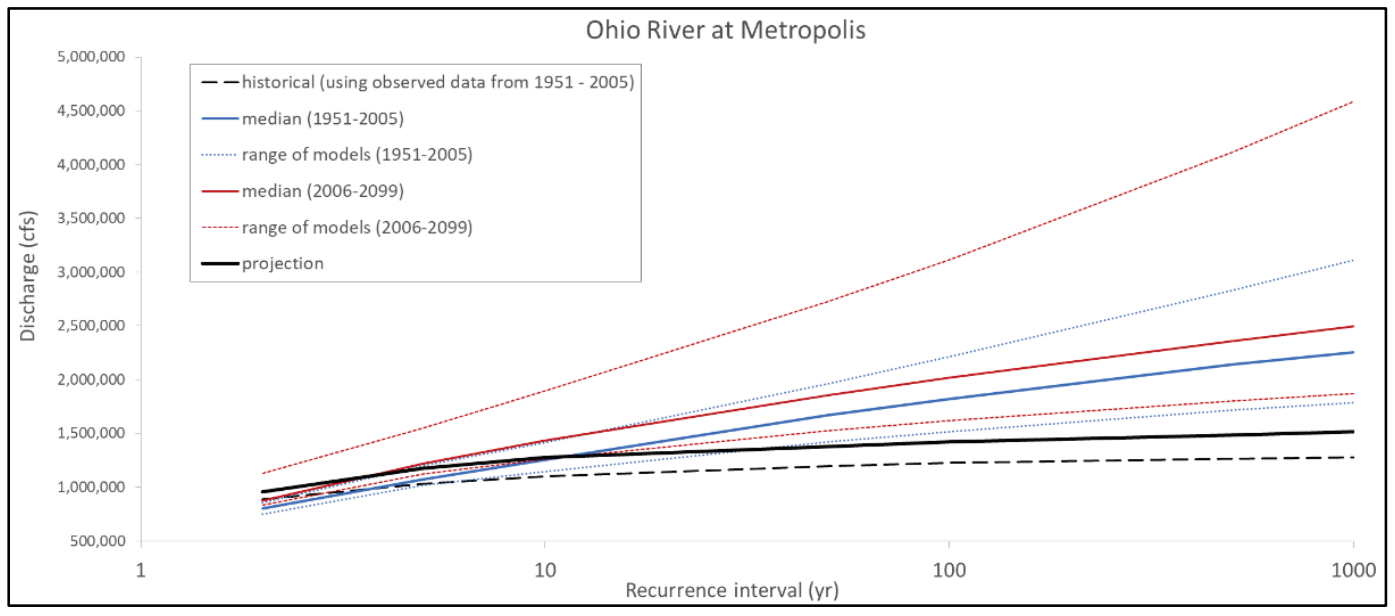




\section{Conclusions}

CMIP5 daily total runoff data were used in the RAPID model to simulate daily flows in 1.2 million river segments over the entire MRB from 1950 to 2099. The following list of conclusions can be drawn from this effort:

- Models vary significantly from the recorded flows during the historical time period. This is primarily due to the uncertainties in inputs for the RAPID model, as is demonstrated by the wide range of climate model results.

- Many climate models predict extremely high flow events occurring at greater magnitudes, or at higher frequencies, in the future.

- Using the chi-squared test to compare the models, the FGOALS-g2 model was the best-performing model at the most locations across the MRB.

- The recurrence interval analysis of modeling results generally shows an overestimation of the discharges in comparison with the observations during the historical time period. The primary cause(s) of the overestimation should be investigated further.

- Results from this effort can be used to attribute contributing influences between the Ohio River and the Mississippi River above the confluence at Cairo, IL. For the recurrence interval analysis of the future time period, the magnitude of flow of the Ohio River at Metropolis, IL, is expected to increase more than the Mississippi River at Thebes, IL.

- Results indicate that the hydrologic conditions of the Mississippi River are not stationary and that discharges associated with the extreme events are projected to increase in the future. This is an important finding in terms of the design and operation of the MR\&T System.

Future work could consider a comprehensive analysis of climate models for the other representative concentration pathway scenarios. Further investigation into how the statistical properties change over the future time period (e.g., in 20-year periods) is also recommended. Additionally, a seasonal assessment demonstrating how seasonal flows may change over time could also provide valuable insight to potential future flows within the MRB. 


\section{References}

Ahmadalipour A., A. Rana, H. Moradkhani, and A. Sharma. 2015. "Multi-Criteria Evaluation of CMIP 5 GCMs for Climate Change Impact Analysis." Theoretical and Applied Climatology 128(1-2): 71-78. doi:10.1007/s00704-015-1695-4

Brekke, L., A. Wood, and T. Pruitt. 2014. Downscaled CMIP3 and CMIP5 Hydrology Projections - Release of Hydrology Projections, Comparison with Preceding Information and Summary of User Needs. U.S. Department of the Interior, Bureau of Reclamation. http://gdodcp.ucllnl.org/downscaled_cmip_projections/techmemo/BCSD5HydrologyMemo.pdf

David, C. H., J. S. Famiglietti, Z.-L. Yang, and V. Eijkhout. 2015. "Enhanced Fixed-Size Parallel Speedup with the Muskingum Method Using a Trans-Boundary Approach and a Large Sub-Basins Approximation." Water Resources Research 51(9): 7547-7571. doi: 10.1002/2014WR016650

David, C. H., F. Habets, D. R. Maidment, and Z.-L. Yang. 2011a. "RAPID Applied to the SIM-FRANCE Model.” Hydrological Processes 25(22): 3412-3425. doi: 10.1002/hyp.8070

David, C. H., D. R. Maidment, G.-Y. Niu, Z.- L. Yang, F. Habets, and V. Eijkhout. 2011b. "River Network Routing on the NHDPlus Dataset." Journal of Hydrometeorology 12(5): 913-934. doi: 10.1175/2011JHM1345

David, C. H., Z.-L. Yang, and J. S. Famiglietti. 2013. "Quantification of the Upstream-toDownstream Influence in the Muskingum Method, and Implications for Speedup in Parallel Computations of River Flow." Water Resources Research 49(5): 2783-2800. doi: $10.1002 /$ wrcr.20250

DeHaan, H., J. Stamper, and B. Walters. 2012. Mississippi River and Tributaries System 2011 Post-Flood Report. U.S. Army Corps of Engineers: Mississippi Valley Division.

ESRI. 2011. ArcGIS Desktop: Release 10. Redlands, CA: Environmental Systems Research Institute.

Flato, G., J. Marotzke, B. Abiodun, P. Braconnot, S.C. Chou, W. Collins, P. Cox, F. Driouech, S. Emori, V. Eyring, C. Forest, P. Gleckler, E. Guilyardi, C. Jakob, V. Kattsov, C. Reason, and M. Rummukainen. 2013. "Evaluation of Climate Models." Climate Change 2013: The Physical Science Basis. Contribution of Working Group I to the Fifth Assessment Report of the Intergovernmental Panel on Climate Change. Edited by T. F. Stocker, D. Qin, G.-K. Plattner, M. Tignor, S.K. Allen, J. Boschung, A. Nauels, Y. Xia, V. Bex, and P. M. Midgley, 741-866. Cambridge, UK: Cambridge Univ. Press.

Follum, M. L., A. A. Tavakoly, J. D. Niemann, and A. D. Snow. 2017. “AutoRAPID: A Model for Prompt Streamflow Estimation and Flood Inundation Mapping over Regional to Continental Extents." Journal of the American Water Resources Association 1-20. doi: 10.1111/1752-1688.12476 
Flipo, N., C. Monteil, M. Poulin, C. de Fouquet, and M. Krimissa. 2012. "Hybrid Fitting of a Hydrosystem Model: Long-Term Insight into the Beauce Aquifer Functioning" (France). Water Resources Research 48(5): Wo5509. doi:10.1029/2011WR011092

Gaines, R. A., S. E. Girdner, and B. J. Frederick. 2018. Mississippi River and Tributaries Flowline Assessment Hydrology Report. MRG\&P Report No. 24, Volume 2. Vicksburg, MS: U.S. Army Engineer Research and Development Center.

Horizon Systems Corporation. 2007. National Hydrography Dataset Plus: Documentation. https://www.epa.gov/waterdata/learn-more\#Documentation

House Document 308. 1964. Mississippi River and Tributaries Project, 88 $8^{\text {th }}$ Congress. Vol. 12644. Washington, DC: U.S. Government Printing Office.

Lewis, J., C. McKinnie, K. Parrish, W. Crosby, C. Cruz. M. Dove, R. A. Gaines, S. Girdner, R. Gambill, D. Ramirez, R. Taylor, M. Agnew, W. Veatch. M. Dircksen, T. Brown, F. Griggs, R. Copeland, B. Rentfro, J. Ashley, J. Windham, and E. Howe. 2018. Mississippi River and Tributaries Flowline Assessment Main Report. MRG\&P Report No. 24; Volume 1. Vicksburg, MS: U.S. Army Engineer Research and Development Center.

Lin, P., Z.-L. Yang, X. Cai, and C. H. David. 2015. "Development and Evaluation of a Physically-Based Lake Level Model for Water Resource Management: A Case Study for Lake Buchanan, Texas.” Journal of Hydrology 4(Part B): 661-674. doi:10.1016/j.ejrh.2015.08.005

Maurer, E. P., A. W. Wood, J. C. Adam, D. P. Lettenmaier, and B. Nijssen. 2002. “A LongTerm Hydrologically-Based Data Set of Land Surface Fluxes and States for the Conterminous United States." Journal of Climate 15(22): 3237-3251.

Mississippi River Commission (MRC). 1955. Memorandum Report No. 1. Appendix J-Mississippi River Basin: Meteorological Study. Mississippi River Commission, U.S. Army Corps of Engineers.

Pearson, K. 2009. "On the Criterion That a Given System of Deviations from the Probable in the Case of a Correlated System of Variables Is Such That It Can Be Reasonably Supposed to Have Arisen from Random Sampling." Philosophical Magazine Series 5. Vol. 50, 1900(302): 157-175. https://doi.org/10.1080/14786440009463897

Saleh, F., N. Flipo, F. Habets, A. Ducharne, L. Oudin, P. Viennot, and E. Ledoux. 2011. "Modeling the Impact of In-Stream Water Level Fluctuations on Stream-Aquifer Interactions at the Regional Scale." Journal of Hydrology 400(3-4): 490-500.

Snow, A. D., S. D. Christensen, N. R. Swain, J. Nelson, D. P. Ames, N. L. Jones, D. Ding, N. Noman, C. H. David, and F. Pappenberger. 2016. "A High-Resolution National Hydrologic Forecast System Downscaled from a Global Ensemble Land Surface Model.” Journal of the American Water Resources Association 52(4): 1-15 doi: $10.1111 / 1752-1688.12434$

Tavakoly, A. A., F. Habets, F. Saleh, Z.-L. Yang, C. Bourgeois, and D. R. Maidment. 2019. "An Integrated Framework to Model Nitrate Contaminants with Interactions of Agriculture, Groundwater, and Surface Water at Regional Scales: The STICSEaudyssée Coupled Models Applied over the Seine River Basin.” Journal of Hydrology 568: 943-958. doi: 10.1016/j.jhydrol.2018.11.061 
Tavakoly, A. A., D. R. Maidment, J. McClelland, T. Whiteaker, Z.-L. Yang, C. Griffin, C. H. David, and L. Meyer. 2016. "A GIS Framework for Regional Modeling of Riverine Nitrogen Transport: Case study, San Antonio and Guadalupe Basins.” Journal of the American Water Resources Association 52(1): 1-15. doi: 10.1111/1752$\underline{1688.12355}$

Tavakoly, A. A., A. D. Snow, C. H. David, M. L. Follum, D. R. Maidment, and Z.-L. Yang. 2017. "Continental Scale River Flow Modeling of the Mississippi River Basin Using High-Resolution NHDPlus Dataset." Journal of the American Water Resources Association 53(2): 258-279. doi: 10.1111/1752-1688.12456

Taylor, K. E., R. J. Stouffer, and G. A. Meehl. 2012. "An Overview of CMIP5 and the Experiment Design.” Bull. Am. Meteorol. Soc. 93(4): 485-498. doi:10.1175/BAMSD-11-00094.1

Thierion, C., L. Longuevergneb, F. Habets, E. Ledoux, P. Ackerer, S. Majdalani, E. Leblois, S. Lecluse, E. Martin, S. Queguiner, and P. Viennot. 2012. "Assessing the Water Balance of the Upper Rhine Graben hydrosystem." Journal of Hydrology 424-425: 68-83.

Törnqvist, R., J. Jarsjö, J. Pietroń, A. Bring, P. Rogberg, S. M. Asokan, and G. Destouni. 2014. "Evolution of the Hydro-Climate System in the Lake Baikal Basin." Journal of Hydrology 519: 1953-1962. doi: 10.1016/i.jhydrol.2014.09.074 


\section{Appendix: Recurrence Interval Analysis for Additional Locations}

Figure 9. Recurrence interval comparisons for the 1951-2005 time period for the Mississippi River at Thebes, IL.

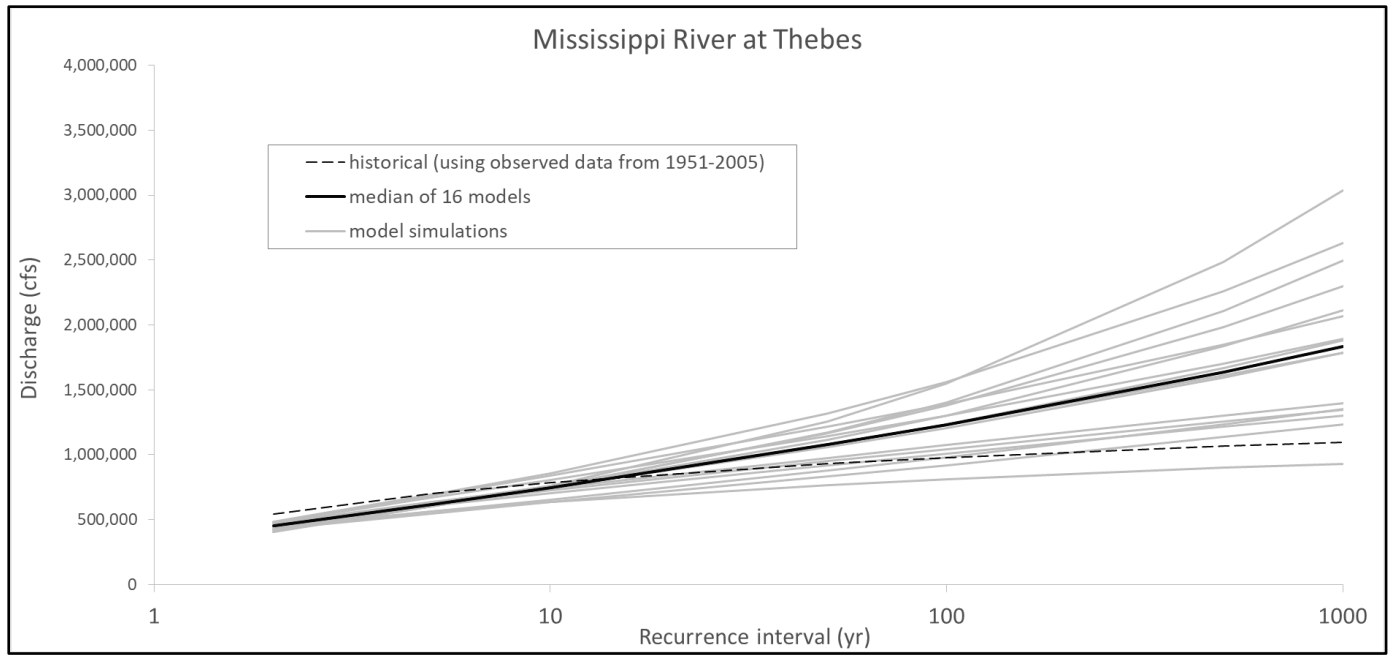

Figure 10. Comparison of recurrence interval changes between the historic and future time periods for the Mississippi River at Thebes, IL.

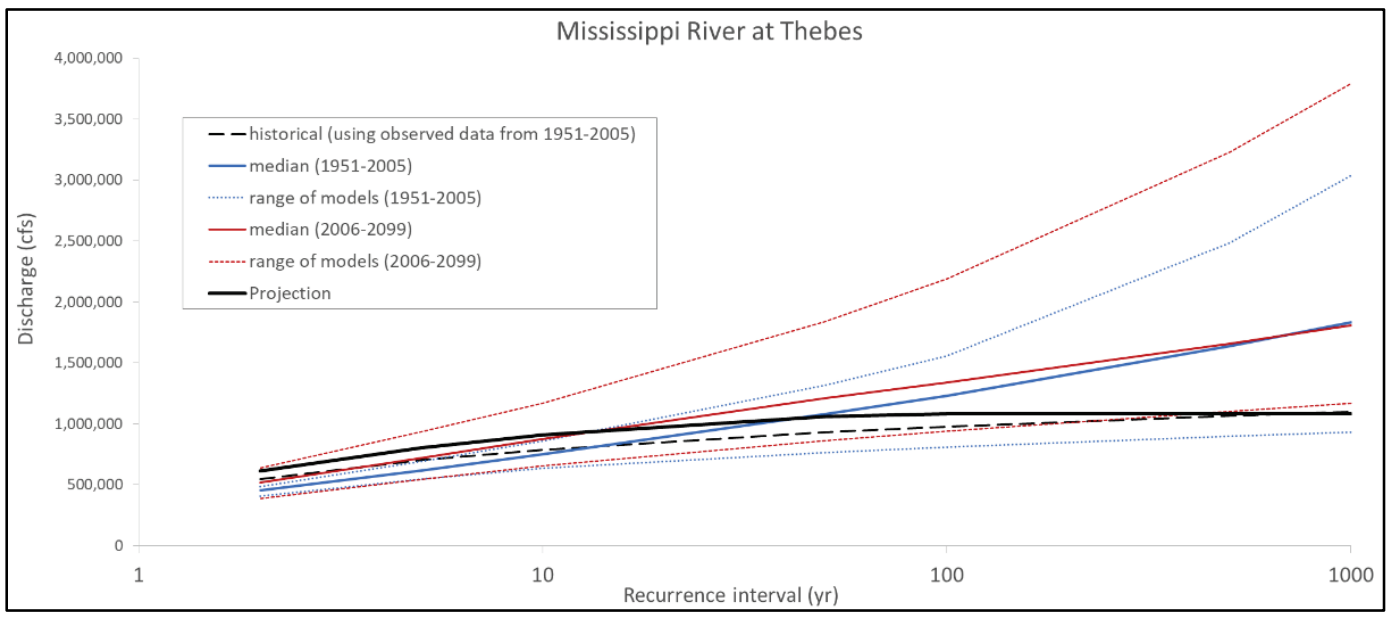


Figure 11. Recurrence interval comparisons for the 1951-2005 time period for the Mississippi River at Helena, AR.

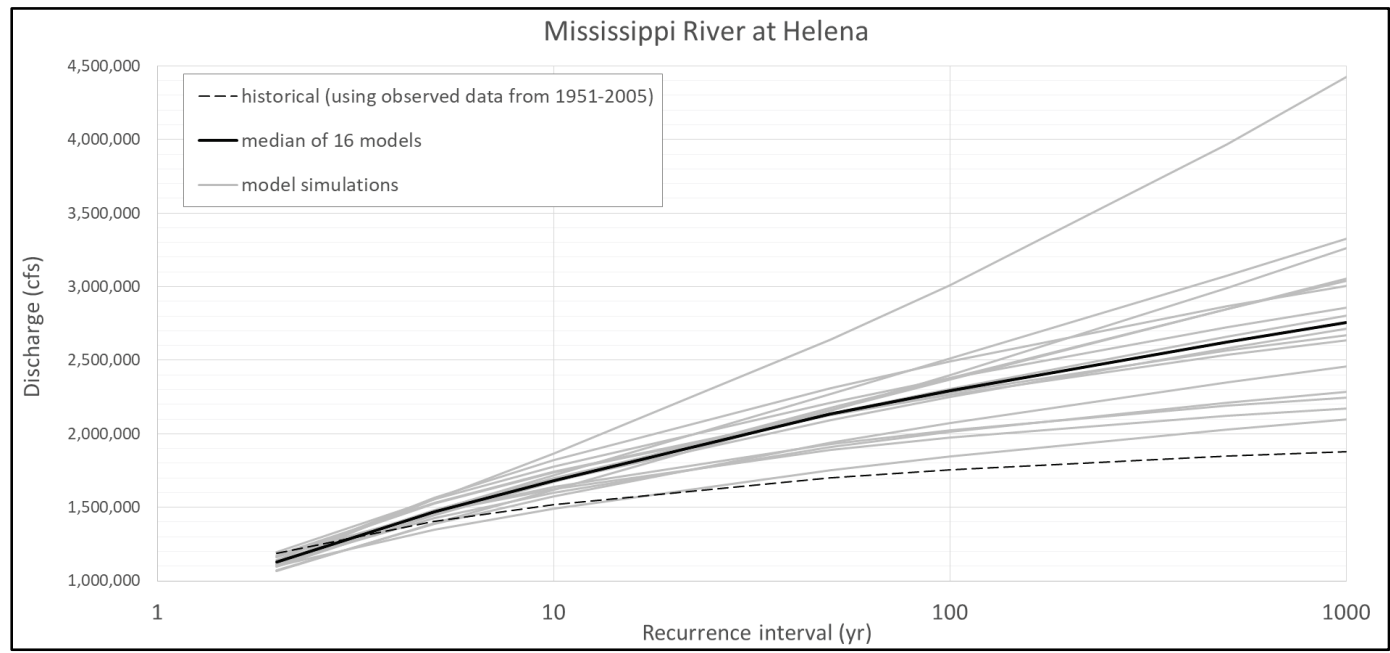

Figure 12. Comparison of recurrence interval changes between the historic and future time periods for the Mississippi River at Helena, AR.

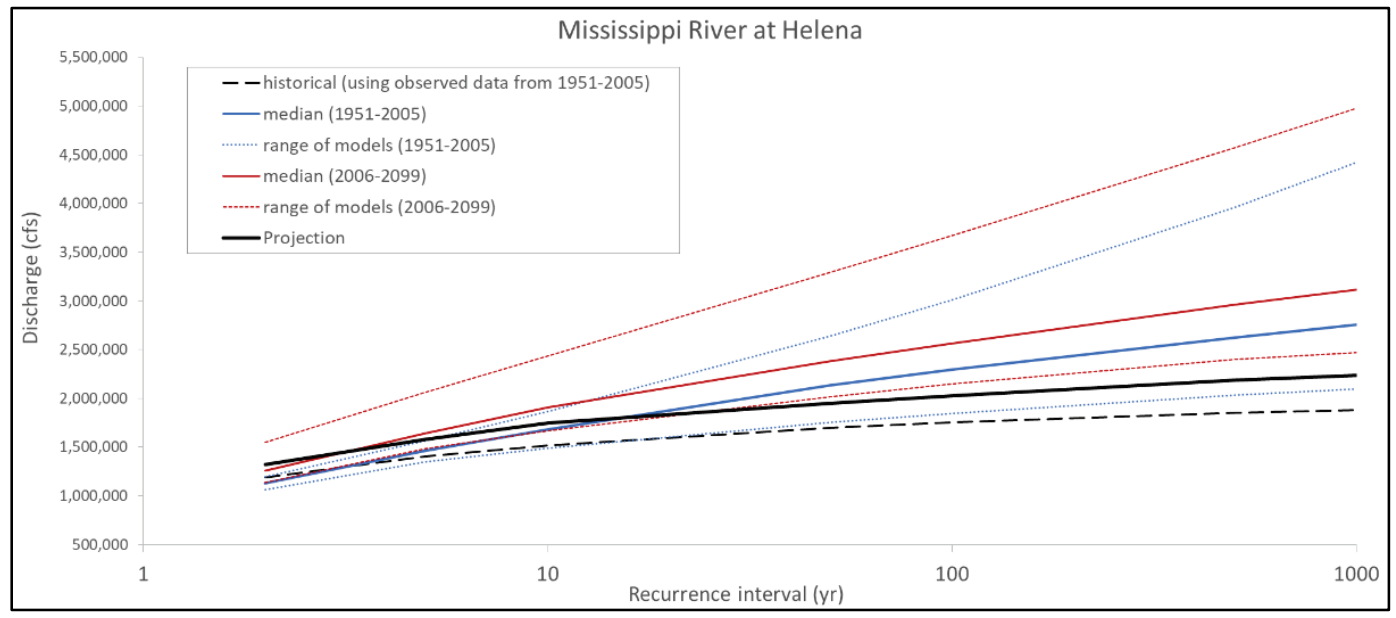


Figure 13. Recurrence interval comparisons for the 1951-2005 time period for the Mississippi River at Vicksburg, MS.

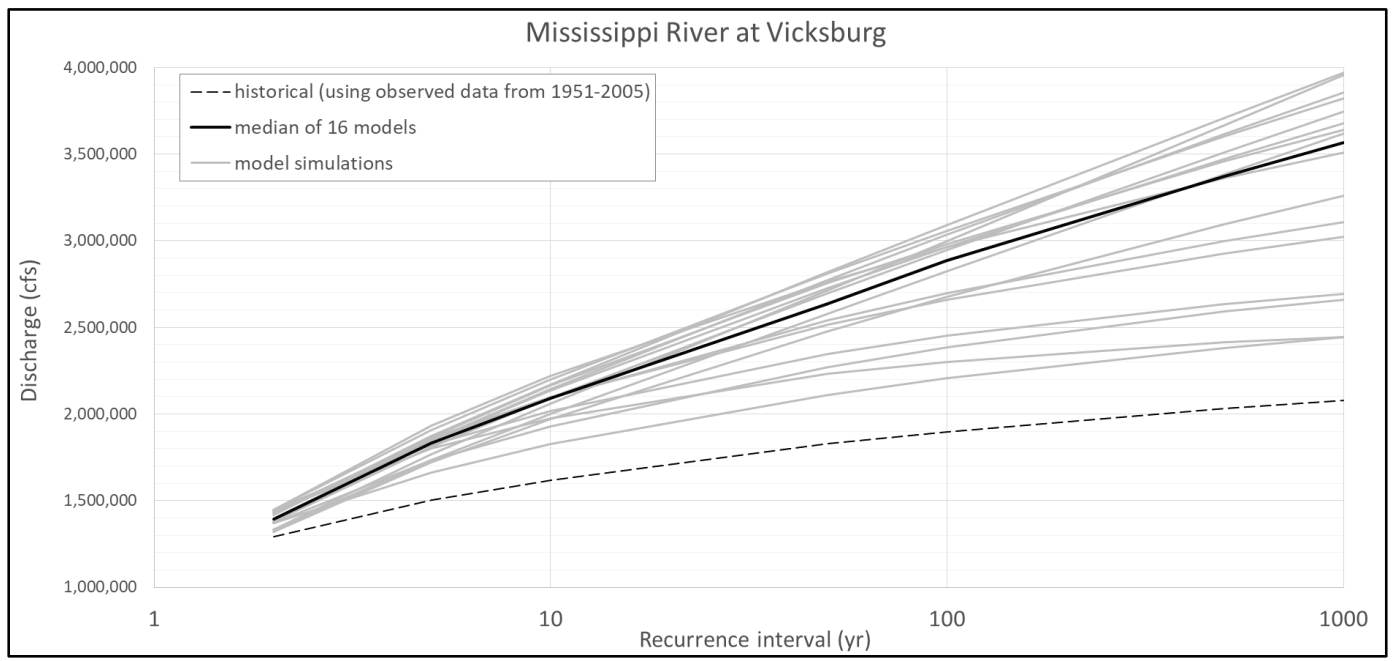

Figure 14. Comparison of recurrence interval changes between the historic and future time periods for the Mississippi River at Vicksburg, MS.

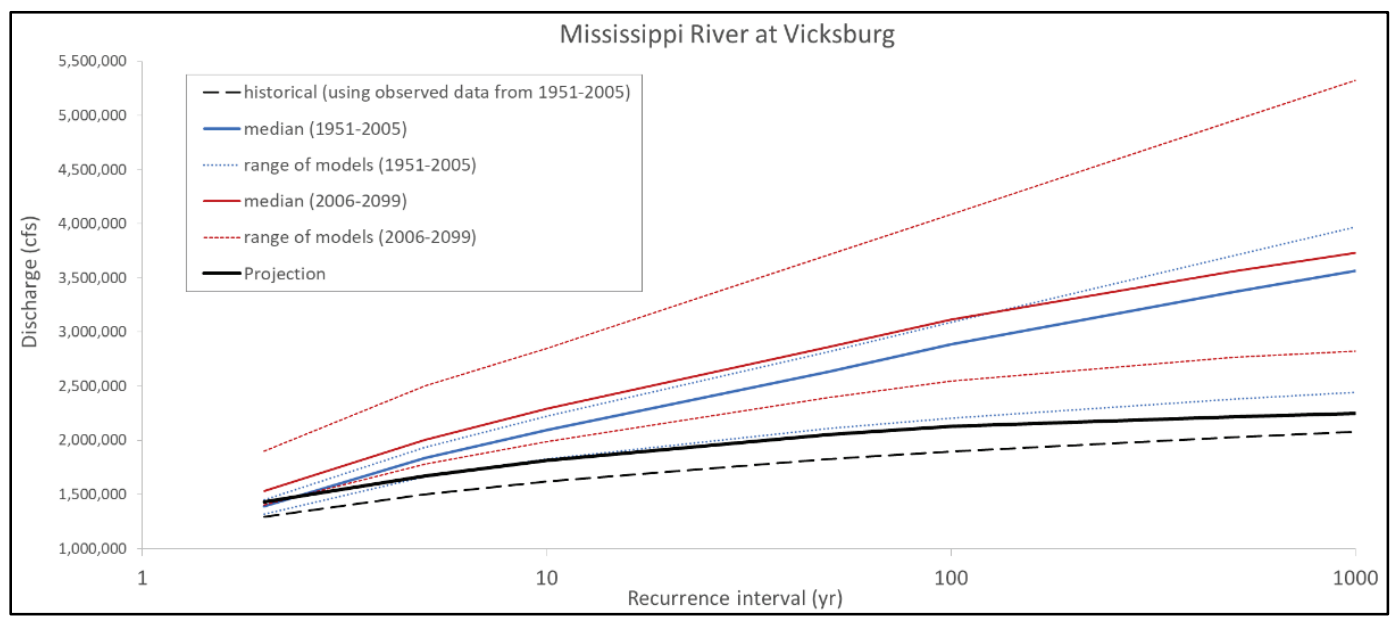


Figure 15. Recurrence interval comparisons for the 1951-2005 time period for the Mississippi River at Natchez, MS.

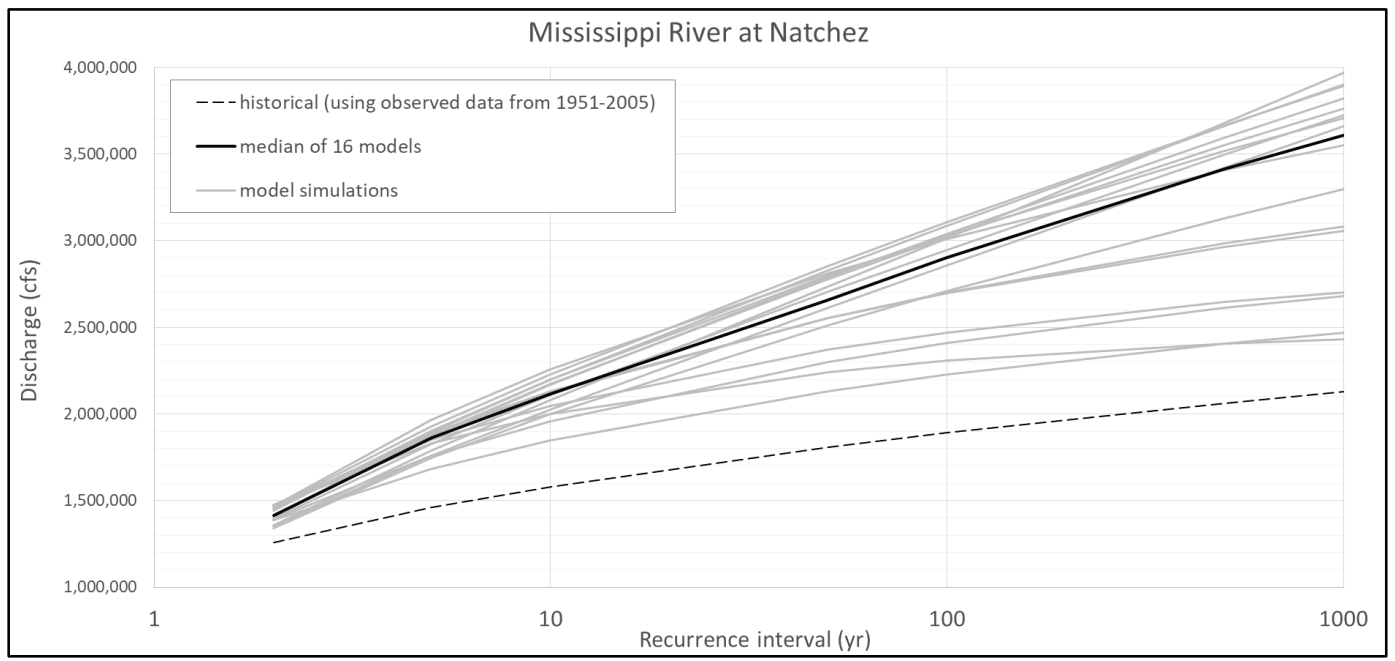

Figure 16. Comparison of recurrence interval changes between the historic and future time periods for the Mississippi River at Natchez, MS.

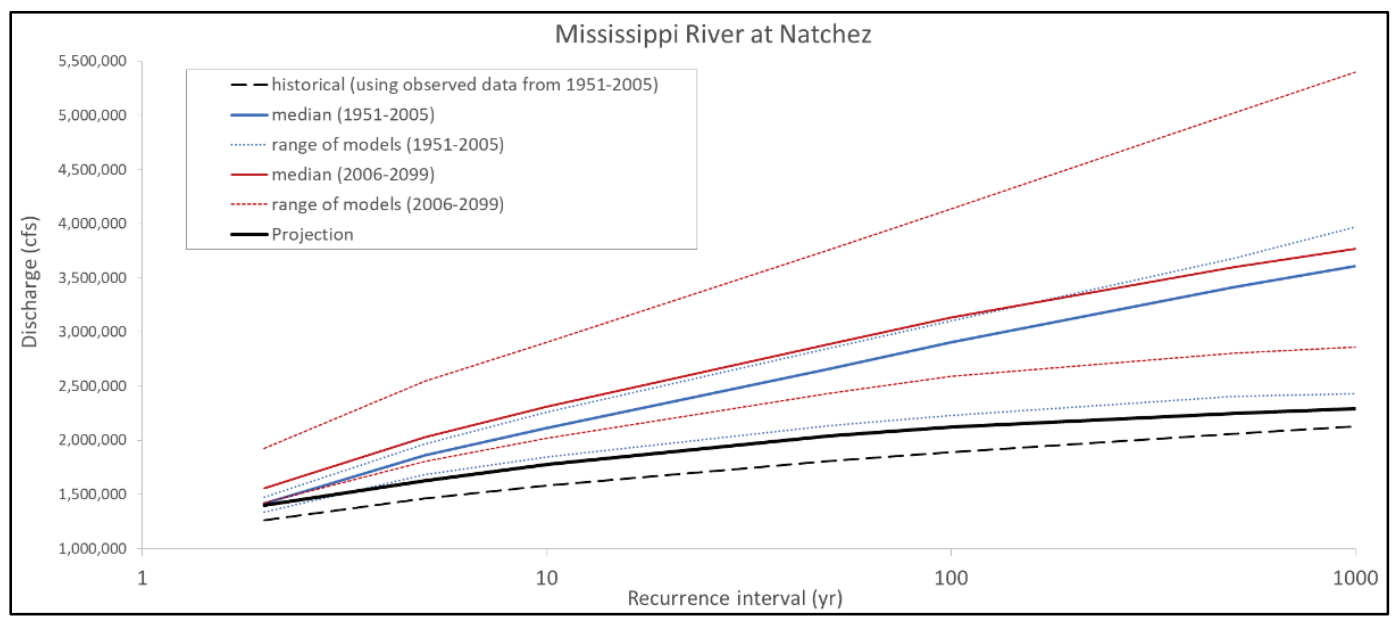




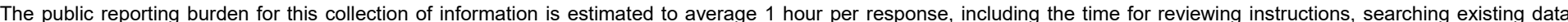

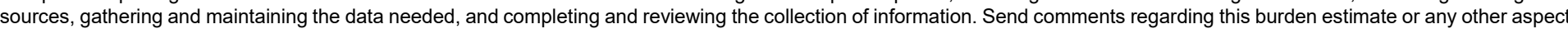

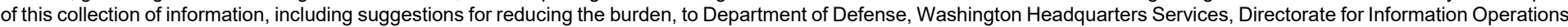

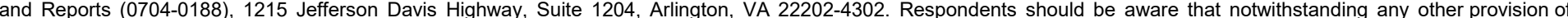
law, no person shall be subject to any penalty for failing to comply with a collection of information if it does not display a currently valid OMB control number. PLEASE DO NOT RETURN YOUR FORM TO THE ABOVE ADDRESS.

\begin{tabular}{l|l|l}
\hline 1. REPORT DATE & $\begin{array}{l}\text { 2. REPORT TYPE } \\
\text { Final Report }\end{array}$ & 3. DATES COVERED (From - To) \\
September 2019 & \begin{tabular}{l} 
Final \\
\hline
\end{tabular}
\end{tabular}

\section{TITLE AND SUBTITLE}

Mississippi River and Tributaries Future Flood Conditions 5a. CONTRACT NUMBER

5b. GRANT NUMBER

5c. PROGRAM ELEMENT NUMBER

5d. PROJECT NUMBER

470711

5e. TASK NUMBER

5f. WORK UNIT NUMBER

8. PERFORMING ORGANIZATION REPORT NUMBER

MRG\&P Report No. 28

10. SPONSOR/MONITOR'S ACRONYM(S)

USACE MVD MRG\&P

11. SPONSOR/MONITOR'S REPORT NUMBER(S)

Vicksburg, MS 39180

\section{DISTRIBUTION/AVAILABILITY STATEMENT}

Approved for public release; distribution is unlimited.

\section{SUPPLEMENTARY NOTES}

\section{ABSTRACT}

The Mississippi River and Tributaries protection system is designed according to the Project Design Flood (PDF), or the largest storm series with a reasonable chance of occurrence over the Mississippi River Basin. This report considers a new approach to generate hypothetical extreme flow conditions for the entire Mississippi River Basin. Utilizing recent advancements in computer modeling and climate science, a vector-based continental-scale river routing model was developed for the entire Mississippi River Basin. Daily flows within all river segments were computed for 1.2 million river reaches over the time period of 1950 through 2099 and for 16 different climate scenarios. An ensemble of varying climate simulations were executed using the Routing Application for Parallel computatIon of Discharge river routing model. The 16 projections were from the Coupled Model Intercomparison Project, Phase 5, climate model projections. Daily flow results for the 65 key locations were analyzed for the historical (1950-2005) and the projected (2006-2099) time periods. Results indicate that the hydrologic conditions of the Mississippi River are not stationary and that discharges associated with the extreme events are projected to increase in the future.

\section{SUBJECT TERMS}

Computer simulation, Flood control, Hydraulic models, Mathematical models, Mississippi River, Mississippi River Watershed, Numerical analysis

16. SECURITY CLASSIFICATION OF:

a. REPORT

Unclassified

\section{b. ABSTRACT}

Unclassified c. THIS PAGE

Unclassified
17. LIMITATION OF ABSTRACT

SAR
18. NUMBER OF PAGES

32 19a. NAME OF RESPONSIBLE PERSON

19b. TELEPHONE NUMBER (Include area code) 601-634-5062 